\title{
The Silurian stage boundaries in Bulgaria: the challenge of the Aeronian/Telychian (Llandovery) boundary
}

\author{
Valeri Sachanski
}

University of Mining and Geology, Department of Geology and Geoinformatics, Studentski Grad, Prof. Boyan Kamenov Str., 1700 Sofia, Bulgaria;

Geological Institute, Bulgarian Academy of Sciences, Acad. G. Bonchev Str., Bl. 24, 1113 Sofia, Bulgaria;

e-mail:v_sachanski@geology.bas.bg

(Accepted in revised form: October 2017)

\begin{abstract}
The upper Aeronian to lower Telychian (Llandovery Series, lower Silurian) strata in the parastratotype for the Saltar Formation (chert-shale succession) are documented in terms of their lithologies and graptolite biostratigraphy. The studied section Asaritsa crops out in the western sector of the Stara Planina Mountains (Svoge Unit of the Srednogorie Zone). In section Asaritsa, the highest Aeronian graptolitic strata are separated from the lowest Telychian graptolitic strata by a graptolite-barren interval of pale-coloured shale. Based on the graptolites documented below and above this interval, as well as on its correlation to sections studied in detail from the Czech Republic and Spain, the immediate underlay of the pale-coloured shale is referred to the uppermost part of the sedgwickii Zone, the complete pale-coloured shale interval, or its greatest part, to the lower guerichi Zone, and the directly overlying it succession to the upper part of the guerichi Zone. The Aeronian/Telychian boundary is assumed to lie at the base of this pale-coloured shale package, or within its lower part. The study provides documentation of Metaclimacograptus undulatus, Parapetalolithus praecedens, Rastrites carnicus, Rivagraptus bellulus, and illustrations of Stimulograptus for the first time in Bulgaria.
\end{abstract}

Sachanski, V. 2017. The Silurian stage boundaries in Bulgaria: the challenge of the Aeronian/ Telychian (Llandovery) boundary. Geologica Balcanica 46 (2), 3-10.

Keywords: Aeronian/Telychian boundary, graptolites, Bulgaria.

\section{INTRODUCTION}

The boundaries of the Silurian System in Bulgaria are very well documented (Sačanski, 1993) by the first appearance of Akidograptus ascensus for its lower boundary and by Monograptus uniformis for its upper boundary. As opposed to them, the tracing of several stage boundaries within this system is not convincingly motivated. Most problematic appears to be the Aeronian/Telychian boundary (middle to upper Llandovery Series). The base of the Telychian Stage has long been recognised as poorly defined biostratigraphically at its GSSP in the type Llandovery area (Loydell et al., 2015, and references therein). As a result, for practical purposes, most authors have simply assumed that the base of the Telychian and that of the Spirograptus guerichi graptolite Biozone coincide. Commonly, what mostly hampers the correct recognition of this boundary is the fact that in many sections around the world the highest Aeronian graptolitic strata are separated from the lowest Telychian graptolitic strata by lithologies yielding either no graptolites or too few to be of great biostratigraphical value (Štorch and Frýda, 2012; Loydell et al., 2015, and references therein). On the other hand, the Llandoverian successions in Bulgaria have been greatly influenced by Variscan and Alpine deformations. Commonly, the undisturbed sections do not exceed several metres. So far, the only documented section that includes the uppermost Aeronian Stimulograptus sedgwickii graptolite Biozone and the lower Telychian Spirograptus guerichi graptolite Biozone is situated in the western sector of the Stara Planina Mts, $\sim 2 \mathrm{~km}$ to the southwest of Yablanitsa Village, Sofia District. The aim of this paper is to document the upper Aeronian and lower Telychian graptolitic strata through this section. 


\section{GEOLOGICAL SETTING}

In terms of regional tectonic zonation, the study area (Fig. 1) is a part of a first-rank Late Alpine tectonic unit, the Srednogorie Zone, represented by the Svoge Unit (Ivanov, 1988; Dabovski and Zagorchev, 2009). The Svoge Unit is the northernmost fragment of the Srednogorie Zone and is thrust to the north over the West Balkan Unit of the Balkan Zone. The NeogeneQuaternary Sofia Graben is superimposed onto the Svoge Unit from the southwest.

The pre-Mesozoic basement of the unit is a technically overprinted Palaeozoic, mainly shale succession that is topped by Upper Devonian to lowermost Carboniferous flysch. This sequence is a part of the Palaeozoic Balkan Terrane (Yanev, 2000; Yanev et al., 2005). The latter is overlain, with angular unconformity, by Upper Carboniferous and/or Permian clastics. The Llandoverian sedimentological succession is built up mostly of thin-bedded, dark grey to black cherts (lydites), organic-rich shales, and siliceous shales of the Saltar Formation (Sachanski and Tenchov, 1993), which covers, with a sharp lithological but conform-

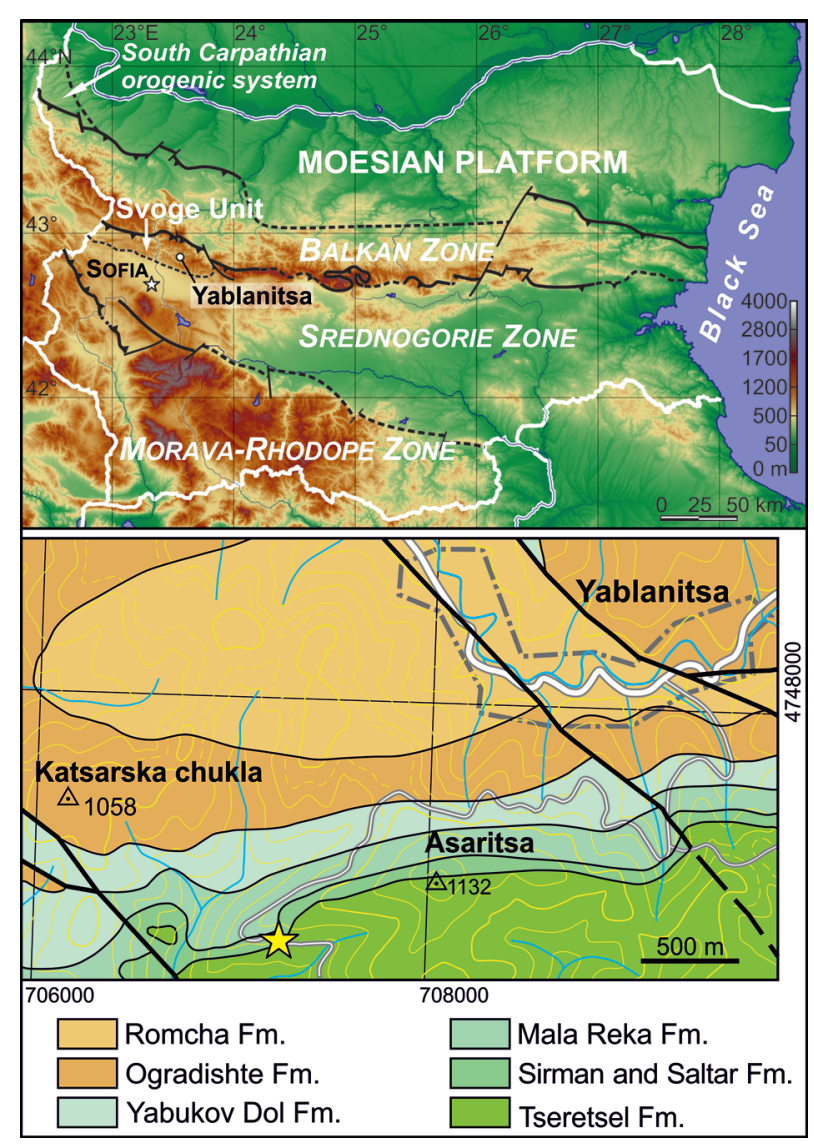

Fig. 1. Alpine tectonic subdivision of Bulgaria (simplified after Dabovski and Zagorchev, 2009) and geological map of the studied area (after Angelov et al., 2010) with designated location (yellow star) of the Asaritsa section. able contact, the Hirnantian glaciomarine deposits (Chatalov, 2014, 2017). The chronostratigraphical range of the chert-shale succession has been determined to span the upper Hirnantian Stage of the Upper Ordovician Series to the lower Telychian Stage of the Llandovery Series, based on graptolites (Sachanski, 2015, and references therein). In the middle of this sequence, Sachanski (in: Sachanski and Tenchov, 1993) reported one undisturbed section, situated at $\sim 800 \mathrm{~m}$ to the southwest of Asaritsa Peak, which includes the upper part of the Aeronian and the lowermost part of the Telychian (Llandovery Series). The section also contains a 6-m thick interval of graptolite-barren palecoloured shale. It has been recognised as a parastratotype for the middle part of the Saltar Formation.

\section{MATERIALS AND METHODS}

In 2017, a re-study was made of the Asaritsa section, and its main aim was a new, detailed lithological description and clarification of the graptolite assemblage close to the graptolite-barren pale-coloured shale. Graptolites were collected from selected levels at intervals of 5-10 cm (Figs 2, 3). Level As-G1 is situated in the tectonically undisturbed lower part of the section. This level yielded a considerably rich (50

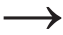

Fig. 2. Generalised lithostratigraphic column of the Silurian in the Svoge Unit of the Srednogorie Zone, Llandovery time scale with graptolite biozonation (Melchin et al., 2012), sea-level curves of Loydell (1998) and Johnson (2006), and lithostratigraphic column of the Aeronian/Telychian boundary sedimentary succession in El Pintado section 1 in Seville Province, Spain (after Loydell et al., 2015; modified), Radotín tunnel section in Bohemia (after Štorch et al., 2011; Štorch and Frýda, 2012; modified) and section Asaritsa with rangechart (after Zalasiewicz et al., 2009), and illustrations of the graptolites in the section: $a$-Stimulograptus halli (Barrande), typical specimen, redrawn from Loydell (1993, Text-fig. 15, Fig. 21); b - Stimulograptus sedgwickii (Portlock), typical specimen, redrawn from Loydell (1993, Text-fig. 15, Fig. 19); c-Spirograptus guerichi Loydell, Štorch \& Melchin, holotype, redrawn from Loydell et al. (1993, Text-fig. 6D); $d$ - Parapetalolithus palmeus, lectotype, redrawn from Štorch (2000a); $e$-Rastrites carnicus, typical specimen, redrawn from Storch and Loydell (1992, Fig. 5C); f-Torquigraptus denticulatus, lectotype, redrawn from Zalasiewicz (2008); $g$ - Rastrites linnaei (Barrande), holotype, redrawn from Storch and Loydell (1992, Fig. 5F); $h$-Rivagraptus bellulus (Törnquist), typical specimen, redrawn from Storch (1998, Text-fig. 2, Fig. 9A); $i-$ Parapetalolithus minor (Elles), typical specimen, redrawn from Bouček and Přibyl (1941a, Text-fig. 1g); $j$ - Normalograptus scalaris (Hisinger), typical specimen, redrawn from Loydell (1992, Text-fig. 11, Fig. 29); $k$-Parapetalolithus praecedens Bouček \& Přibyl, holotype, redrawn from Bouček and Přibyl (1941b, Text-fig. 2, Fig. 14); l-Metaclimacograptus undulates (Kurck), typical specimen, redrawn from Loydell (1992, Textfig. 11, Fig. 9). 


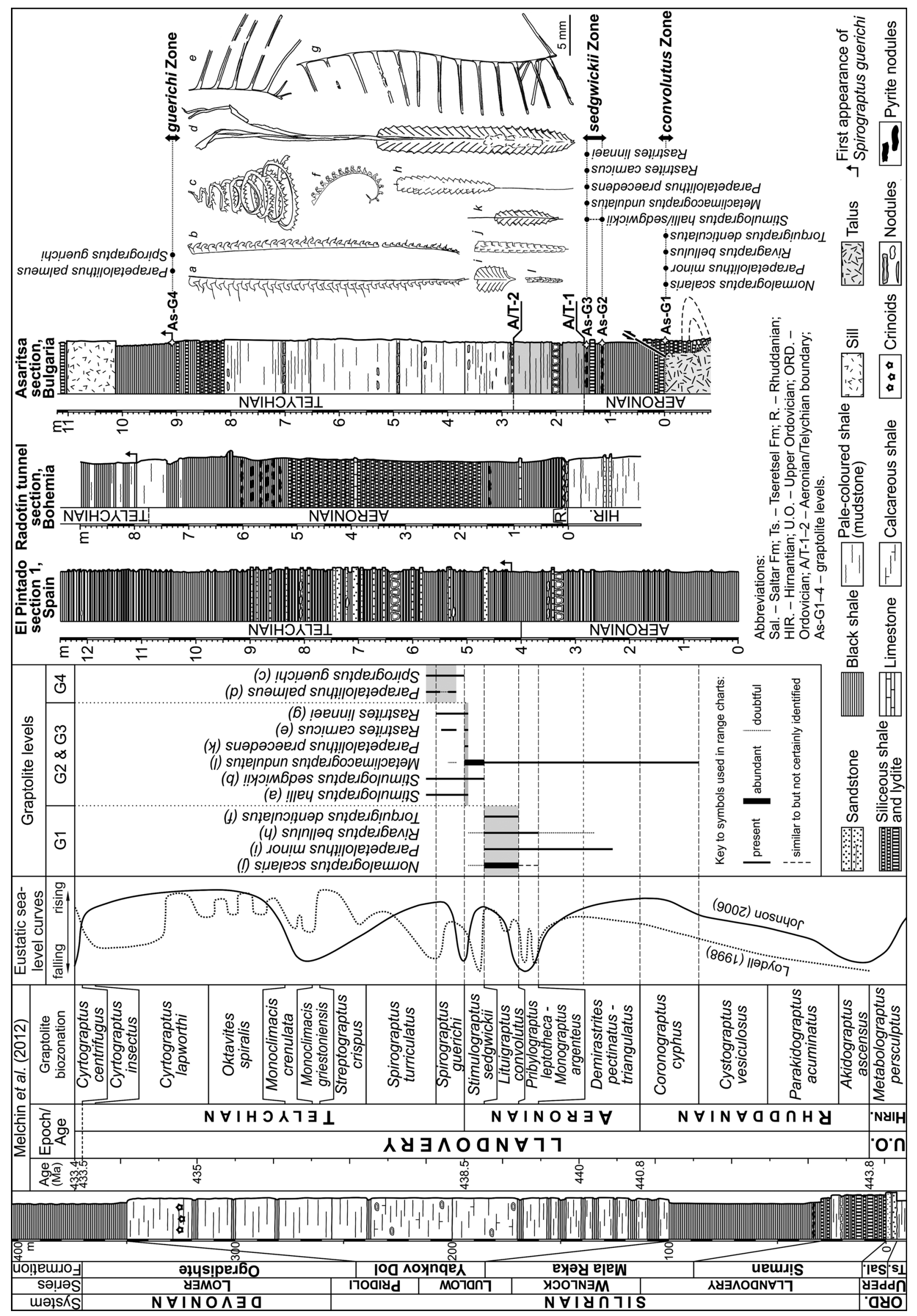



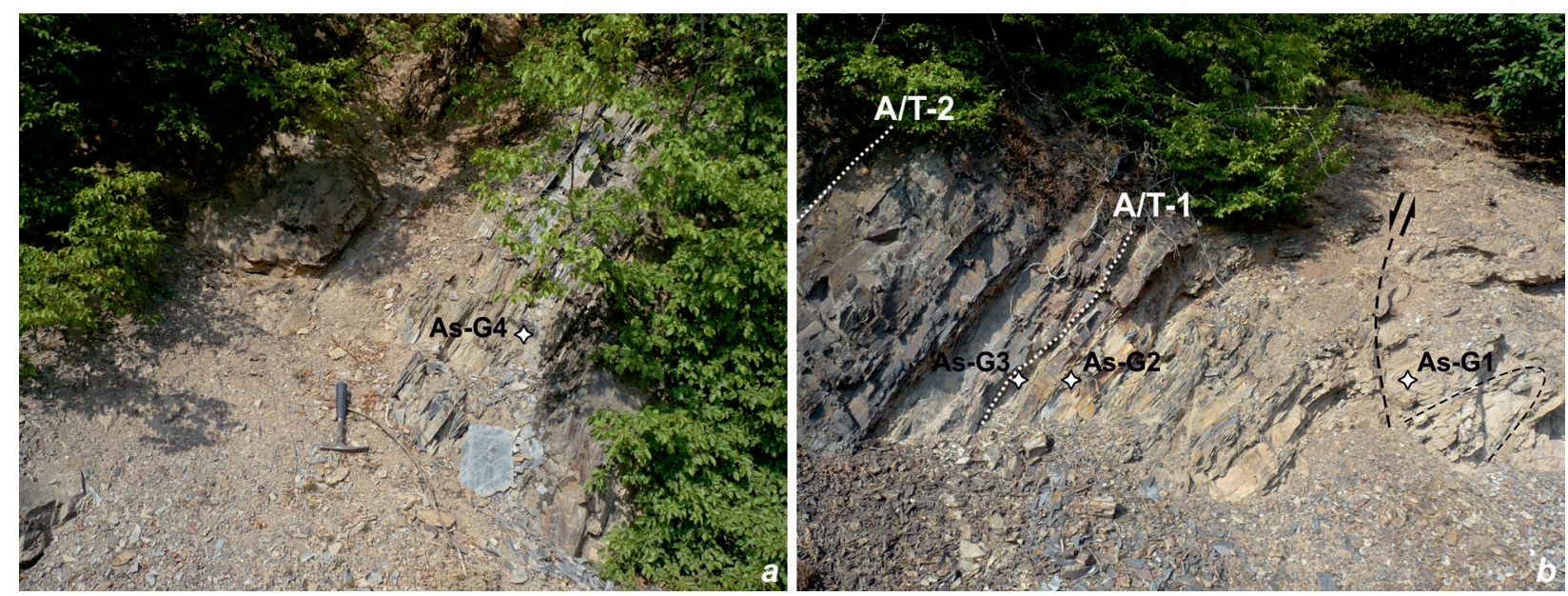

Fig. 3. Field photographs of the Asaritsa section, with designated location of the graptolite levels (As-G1-4) and the alleged position of the Aeronian/Telychian boundary (A/T-1 and A/T-2): $a$ - The upper part of the section (Sachanski, 2015, Fig. 4.3); $b-$ The lower part of the section (Sachanski, 2015, Fig. 4.2). Geographic coordinates of the photos: $a-$ N42 $^{\circ} 50^{\prime} 41.9^{\prime \prime}$ E02332'10.7"; $b-\mathrm{N} 42^{\circ} 50^{\prime} 41.7^{\prime \prime} \mathrm{E} 023^{\circ} 32^{\prime} 11.1^{\prime \prime}$. The geographic coordinates of these photos in Sachanski (2015) are inaccurate, as well as those in his Fig. 5.1, for which the correct coordinates are N42 $50^{\prime} 42.5^{\prime \prime} \mathrm{E} 023^{\circ} 32^{\prime} 0.2^{\prime \prime}$.

species), completely and well-preserved graptolite assemblage. Level As-G2 (6 specimens) is located $35 \mathrm{~cm}$ below the lower boundary of the graptolite-barren interval, and level As-G3 (10 specimens) is immediately below it. This interval yielded mostly graptolite fragments. The first graptolite finds above the palecoloured shale were documented $1 \mathrm{~m}$ (level As-G4) from the uppermost part of the interval (only two specimens). The preservation of graptolites as pale films is characteristic for levels As-G1 and As-G2, while, in levels As-G3 and As-G4, they are mainly preserved as flattened, black peridermal films. Pyritised graptolite fragments were also found at level As-G3. The graptolites do not seem to show tectonic distortion.

Graptolites were identified under the binocular microscope and photographed, using a Leica IC90 E digital camera. All graptolite specimens are housed at the Geological Institute, Bulgarian Academy of Sciences.

\section{RESULTS}

The Asaritsa section is exposed in the roadcut of a small forest road running SW of Yablanitsa Village, about $800 \mathrm{~m}$ WSW of Asaritsa Peak. The geographic position is shown in Fig. 3. The section starts with $\sim 20 \mathrm{~cm}$ of thin-bedded $(3-5 \mathrm{~cm})$, black siliceous shales, separated by similar but inclinally folded sediments by normal fault. These sediments (level As-G1) yielded Normalograptus scalaris (75\% of all specimens), Parapetalolithus minor, Rivagraptus bellulus, and Torquigraptus denticulatus (Figs $2,4 i, h, d, m)$. Rivagraptus bellulus is illustrated for the first time in Bulgaria. N. scalaris dominates in the convolutus Zone. Specimens resembling $N$. scalaris, found in the lower leptotheca Zone were described by Zalasievicz et al. (2009) as "similar to $[N$. scalaris] but not certainly identified", and in the overlying sedgwickii Zone as "doubtful" (Fig. 2 ). The top occurrence of $P$. minor is in the convolutus Zone. Riv. bellulus is characteristic for the leptotheca and the convolutus zones (Štorch, 1998). Similar range was also reported by Zalasievicz et al. (2009), as all occurrences documented out of these zones were indicated as "doubtful" (Fig. 2). T. denticulatus is characteristic for the convolutus Zone (Štorch, 1998; Zalasievicz et al., 2009), although it has been reported from the succeeding sedgwickii Zone (Loydell et al., 2015). Based on the above-considered concurrent ranges of taxa found at level As-G1, it could be attributed to the convolutus Zone, although the biozonal index-taxon

Fig. 4. Graptolites from the Asaritsa section: $a-c)$ Stimulograptus halli/sedgwickii, level As-G2; d) Rivagraptus bellulus (Törnquist), level As-G1; e) Parapetalolithus palmeus (Barrande), level As-G4;f) Rastrites carnicus (Seelmeier), level As-G3; g) Metaclimacograptus undulatus (Kurck), level As-G3; h) Parapetalolithus minor (Elles), level As-G1; i) Normalograptus scalaris (Hisinger), level As-G1; j) Rastrites linnaei Barrande, level As-G3; $k$ ) Spirograptus guerichi Loydell, Štorch \& Melchin, level As-G4; l) Parapetalolithus praecedens Bouček \& Přibyl, level As-G3; m) Torquigraptus denticulatus (Törnquist), level As-G1 . 


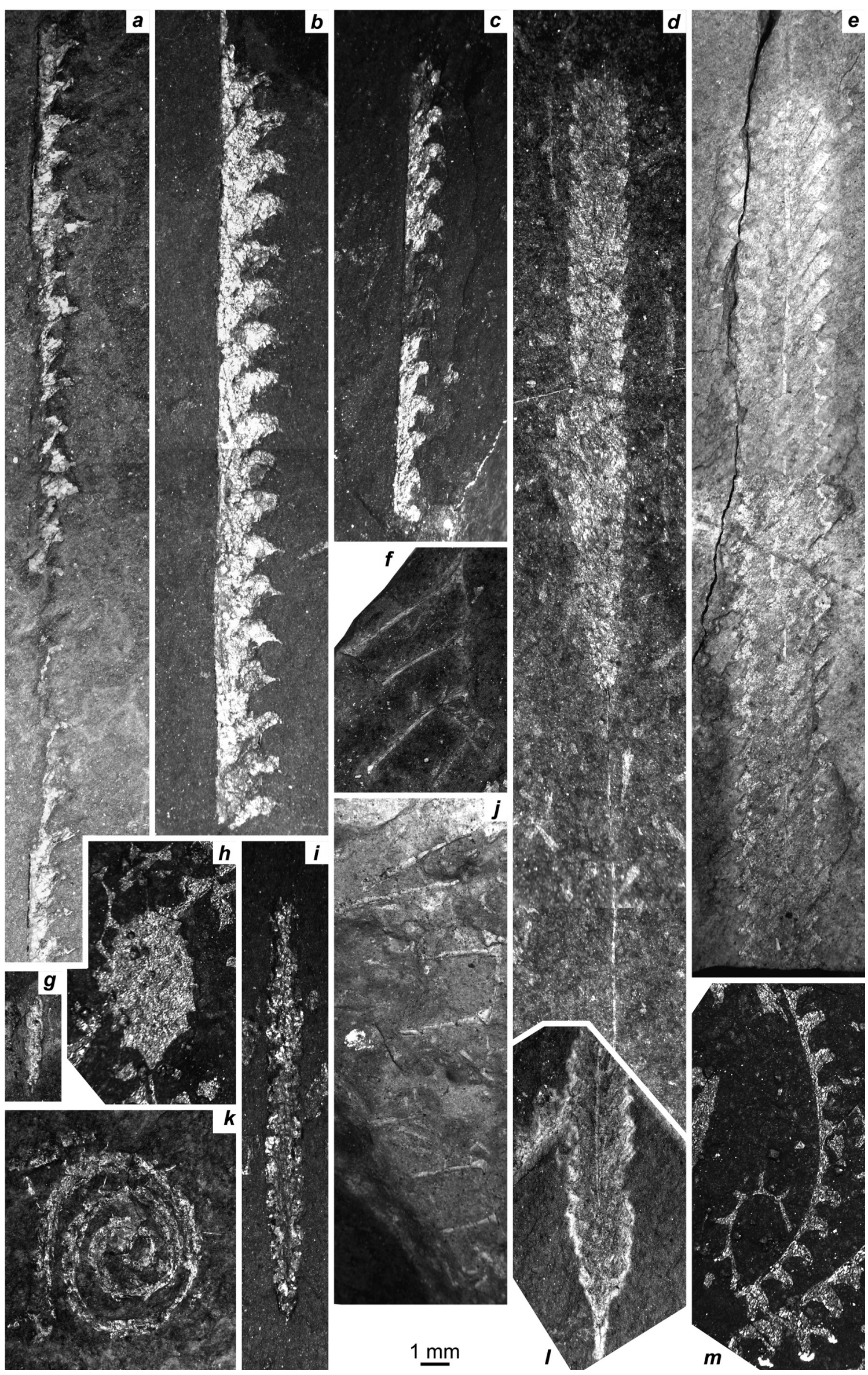


Lituigraptus convolutus was not documented in the present study.

The section continues upwards with a $1.3-\mathrm{m}$ thick interval of very thin beds $(1-3 \mathrm{~cm})$ and thick laminae $(3-10 \mathrm{~mm})$ of black shale. In the uppermost part, they are enriched in pyrite concretions, $1-2 \mathrm{~cm}$ in diameter, and a $10-\mathrm{cm}$ thick interlayer of siliceous shale. Below it, the level As-G2 yielded only distal fragments of Stimulograptus, without possibility for precise species determination or differentiation of St. halli from St. sedgwickii (Loydell, 1993; Loydell et al., 2015). Thus, these fragments have been determined as St. halli/sedgwickii (Figs 2, 4a-c). Similar distal fragments were also found in the uppermost part of the package, together with Metaclimacograptus undulatus, Parapetalolithus praecedens, Rastrites carnicus, and Rastrites linnaei (Figs 2, $4 g, l, f, j$ ). The first three specimens are documented for the first time in Bulgaria. P. praecedens is characteristic for the upper part of the sedgwickii Zone (sensu Melchin et al., 2012; equivalent to the halli Zone sensu Zalasievcz et al., 2009; Loydell et al., 2015), while R. linnaei and $R$. carnicus first appear there, but their stratigraphical range continues up-section in the succeeding guerichi Zone. M. undulatus is a long-ranging taxon, with common occurrence in the sedgwickii Zone (Zalasievcz et al., 2009; Štorch and Frýda, 2012). Based on these data, the uppermost part of these black shales is attributed to the upper part of the sedgwickii Zone (uppermost Aeronian).

Upwards, the succeeding level is represented by a $\sim 6.5-\mathrm{m}$ thick interval of graptolite-barren palecoloured shale. Several levels with concretions occur within the interval (Fig. 2), as the first one, situated 40 $\mathrm{cm}$ above the base of the package, is markedly well sustained, $20 \mathrm{~cm}$ in thickness.

Up-section, a $\sim 1$-m thick packet crops out, comprising very thin-bedded $(1-3 \mathrm{~cm})$, dark grey to grey siliceous shales. This packet is covered by $\sim 1 \mathrm{~m}$ of thick to thin laminae $(1-10 \mathrm{~mm})$ of dark grey to black shales. Parapetalolithus palmeus and Spirograptus guerichi are documented at the base of the latter, being characteristic for the guerichi Zone (lower Telychian), although their occurrence in the lowermost part of the succeeding turriculatus Zone has been reported as well (Zalasievcz et al., 2009).

\section{DISCUSSION AND CONCLUSION}

The results of the present study show that, in the Asaritsa section, the highest Aeronian graptolitic strata are separated from the lowest Telychian graptolitic strata by a graptolite-barren interval, consisting of pale-coloured shale. Similar successions are known and characteristic for different sections around the world, but with variations concerning their lithology and stratigraphical range (Štorch and Frýda, 2012; Loydell et al., 2015, and references therein). When constructing the eustatic sea-level curves, Loydell (1998) and Johnson (2006) associated this sharp lithological change with sea-level drop around the Aeronian/Telychian boundary (Fig. 4).

$P$. praecedens, $R$. carnicus, and $R$. linnaei co-occur in the shale, immediately below the graptolitebarren pale-coloured shale interval (level As-G3), considered to be characteristic for the uppermost part of the sedgwickii Zone (equivalent to the upper halli Zone sensu Loydell et al., 2015). The detailed study of Loydell et al. (2015) of the most continuous graptolitic section through the Aeronian/Telychian boundary revealed the first occurrence of $R$. carnicus $\sim 60 \mathrm{~cm}$ below this boundary. On the other hand, the recognition of nodules or nodular layers at several stratigraphic levels in these sections suggests brief periods of non-deposition to enable their growth (Loydell et al., 2015, and references therein). The first such nodular layer is $20 \mathrm{~cm}$ thick and is located $60 \mathrm{~cm}$ below the Aeronian/Telychian boundary (Fig. 2). Several nodular layers are also documented in the Asaritsa section (Fig. 2). The composition of the nodules and the depositional conditions will be the subject of further investigations.

Štorch and Frýda (2012) provided very useful data through the upper Aeronian to lowermost Telychian of the Prague synform, Bohemia (Czech Republic). The base of the Telychian there lies within a pale, non-graptolitic mudstone unit, only $0.5 \mathrm{~m}$ thick, in the Radotín tunnel section, which is quite similar to that in Bulgaria (Fig. 2). The black shale above the pale mudstone saw the incoming of $R$. linnaei, $S$. guerichi, Torquigraptus planus, Torquigraptus obtusus, Glyptograptus fastigatus, Glyptograptus auritus, Parapetalolithus elongatus, Parapetalolithus palmeus, and Pseudoplegmatograptus sp. T. planus is a species that first appears in the upper part of the guerichi Biozone (Loydell et al., 2015, and references therein). In the Asaritsa section, $1 \mathrm{~m}$ above the pale-coloured shale at level As-G4, only two graptolites were documented ( $P$. palmeus and $S$. guerichi). Based on their occurrence, as well as on the section's resemblance to the Radotín tunnel section in Bohemia, it could be assumed that the grey to black siliceous shales and shales, covering the pale-coloured shale, build up the upper part of the guerichi Biozone, while the greatest part of the pale-coloured shale belongs to lower part of the guerichi Biozone.

The considered data concerning the graptolite levels in the Asaritsa section, as well as the correlation to the thoroughly studied Radotín tunnel section in Bohemia (Štorch and Frýda, 2012) and El Pintado section 1 in Seville Province, Spain (Loydell et al., 2015), support the position of the Aeronian/Telychian boundary either at the base of the graptolite-barren pale-coloured shale interval (A/T-1 - Figs 2,3) or at its lower part, at the second nodular layer, for example, situated $1.3 \mathrm{~m}$ above the base of the interval, 


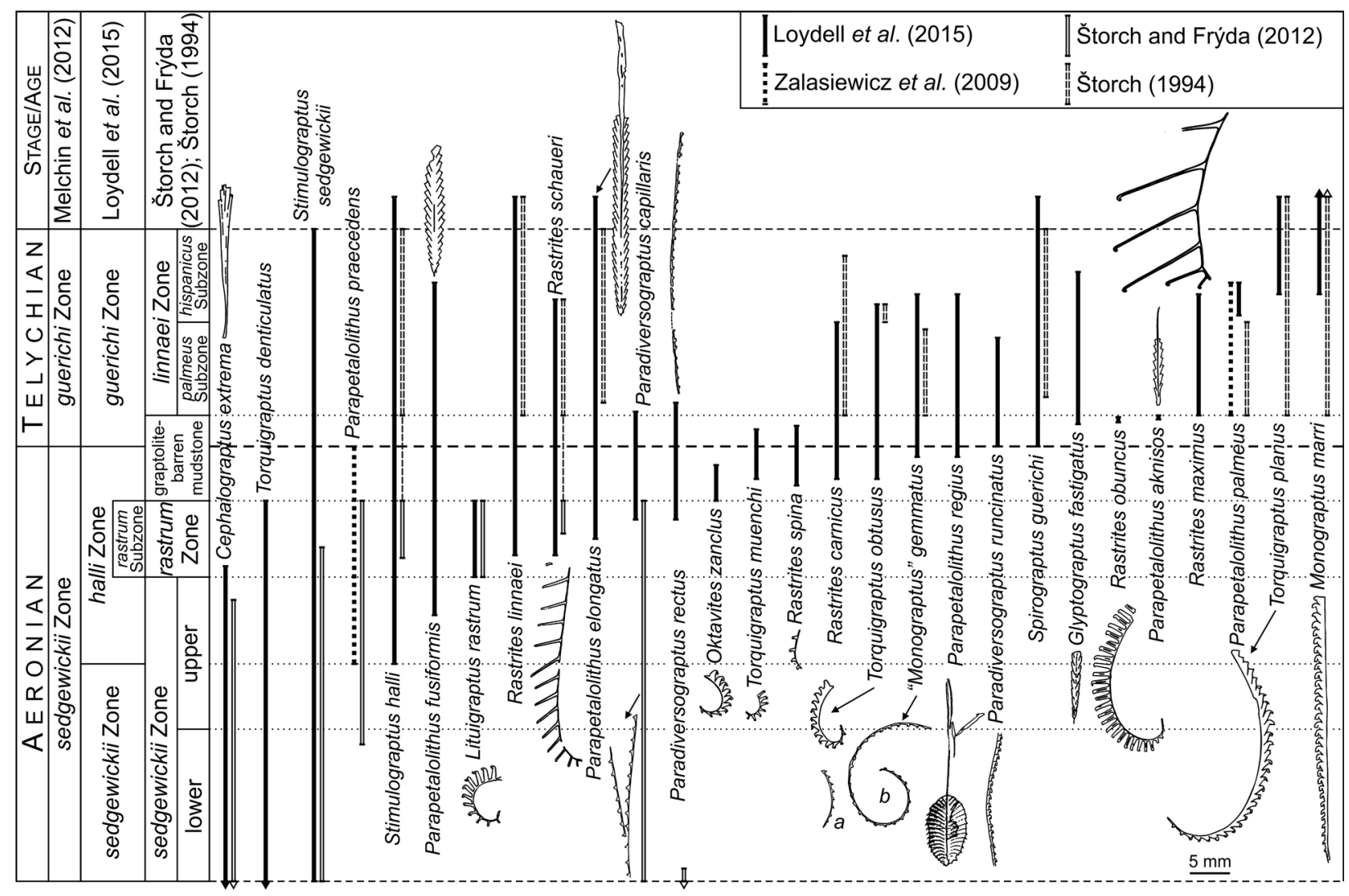

Fig. 5. Graptolite species (range-chart and illustrations) of high stratigraphic value for the Aeronian/Telychian boundary: Cephalograptus extrema Bouček \& Přibyl, holotype, redrawn from Štorch (2008); Parapetalolithus fusiformis (Chen), typical specimen, redrawn from Loydell et al. (2015, Fig. 18AH); Lituigraptus rastrum (Richter), typical specimen, redrawn from Loydell et al. (2015, Fig. 21A); Rastrites schaueri Štorch \& Loydell, holotype, redrawn from Štorch and Loydell (1992, Fig. 5I); Parapetalolithus elongatus (Bouček \& Přibyl), typical specimen, redrawn from Loydell et al. (2015, Fig. 18AP); Paradiversograptus capillaris (Carruthers), holotype, redrawn from Zalasiewicz (2000); Paradiversograptus rectus (Manck), typical specimen, redrawn from Loydell (1993, Text-fig. 26, Fig. 10); Oktavites zanclus Loydell, Frýda \& Gutiérrez-Marco, holotype, redrawn from Loydell et al. (2015, Fig. 21C); Torquigraptus muenchi (Přibyl); typical specimen, redrawn from Loydell et al. (2015, Fig. 21AP); Rastrites spina (Richter), typical specimen, redrawn from Loydell et al. (2015, Fig. 22Q); Torquigraptus obtusus (Schauer), typical specimen, redrawn from Loydell et al. (2015, Fig. 22L); "Monograptus" gemmatus (Barrande), a - typical specimen, redrawn from Loydell (1993, Text-fig. 22, Fig. 29), and $b$ - typical specimen, redrawn from Gutiérrez-Marco and Štorch, (1998, Fig. 8c); Parapetalolithus regius (Hund), typical specimen, redrawn from Bjerreskov (1975, Fig. 12B); Paradiversograptus runcinatus (Lapworth), typical specimen, redrawn from Loydell (1993, Text-fig. 26, Fig. 8); Glyptograptus fastigatus Haberfelner, typical specimen, redrawn from Loydell et al. (2015, Fig. 18B); Rastrites obuncus Loydell, Frýda \& Gutiérrez-Marco, holotype, redrawn from Loydell et al. (2015, Fig. 23T); Parapetalolithus aknisos Loydell, Frýda \& Gutiérrez-Marco, holotype, redrawn from Loydell et al. (2015, Fig. 18X); Rastrites maximus Carruthers, holotype, redrawn from Loydell (2008); Torquigraptus planus (Barrande), holotype, redrawn from Gutiérrez-Marco and Štorch, (1998, Fig. 8j); Monograptus marri Rerner, lectotype, redrawn from Štorch (2000b).

above which the shales acquire a typical light colour (A/T-2 - Figs 2, 3).

Several graptolite species of high stratigraphic value (Fig. 5) are still not documented in Bulgaria (e.g., "Monograptus" gemmatus, Paradiversograptus runcinatus, Lituigraptus rastrum, Oktavites zanclus, as well as determinable proximal fragments or complete rhabdosomes of St. halli and St. sedgwickii). Further detailed study both on the Asaritsa section and on other suitable sections, comprising the considered stratigraphical interval, will contribute to more precise definition of the Aeronian/Telychian boundary in Bulgaria.

\section{Acknowledgements}

This is a contribution to the Project "Rare earth and trace elements in recent and palaeo polymetallic nodules and sediments: temporal and spatial variations, phase and mineral composition" financed by the National Science Fund. Warm thanks are expressed to Prof. Iskra Lakova (Geological Institute, BAS) for much-appreciated critical review of the manuscript. Stoyan Tanatsiev (University of Mining and Geology "St Ivan Rilski", Sofia) is greatly acknowledged for his very important assistance during the field work. 


\section{REFERENCES}

Angelov, V., Antonov, M., Gerdzhikov, S., Tanatsiev, S., Kiselinov, H., Petrov, P., Valev, V. 2010. Geological map of the Republic of Bulgaria in scale 1:50 000, Litakovo map sheet. Ministry of Environment and Water, Bulgarian National Geological Survey, Sofia.

Bjerreskov, M. 1975. Llandoverian and Wenlockian graptolites from Bornholm. Fossils and Strata 8, 1-94.

Bouček, B., Přibyl, A. 1941a. O Petalolithech ze skupiny $P$. folium (His.) a o rodu Cephalograptus Hopk. Razpravy II. Tř́dy České Akademie 51 (26), 1-23.

Bouček, B., Přibyl, A. 1941b. Über die Gattung Petalolithus Suess aus dem böhemischen Silur. Mitteilungen der Tschechischen Akademie der Wissenschaften 41, 1-17.

Chatalov, A. 2014. Development of strain fringes in sedimentary rocks: Evidence for deformation of Upper Ordovician glacial diamictites in the western Srednogorie Zone. Geologica Balcanica 43 (1-3), 51-62.

Chatalov, A. 2017. Sedimentology of Hirnantian glaciomarine deposits in the Balkan Terrane, western Bulgaria: Fixing a piece of the north peri-Gondwana jigsaw puzzle. Sedimentary Geology 350, 1-22

Dabovski, H., Zagorchev, I. 2009. Introduction: Mesozoic evolution and Alpine structure. Alpine structure. In: Zagorchev, I., Dabovski, H., Nikolov, T. (Eds), Geology of Bulgaria. Vol. II. Mesozoic geology. "Prof. M. Drinov" Academic Press, Sofia, 30-37 (in Bulgarian, with English abstract).

Gutiérrez-Marco, J.C., Štorch, P. 1998. Graptolite biostratigraphy of the Lower Silurian (Llandovery) shelf deposits of the Western Iberian Cordillera, Spain. Geological Magazine 135 (1), 71-92.

Ivanov, Ž. 1988. Basic structural features of the external zones of theWestern Balkanides. In: Ivanov, Ž. (Ed.), Lineaments as joint structures of folded areas of different age and their metallogeny. Bulgarian Academy of Sciences, Sofia, 49-81 (in Russian).

Johnson, M.E. 2006. Relationship of Silurian sea-level fluctuations to oceanic episodes and events. GFF 128 (2), $115-121$.

Loydell, D.K. 1992. Upper Aeronian and lower Telychian (Llandovery) graptolites from western mid-Wales. Part 1. Palaeontographical Society Monograph 146 (589), 1-55.

Loydell, D.K. 1993. Upper Aeronian and lower Telychian (Llandovery) graptolites from western mid-Wales. Part 2. Palaeontographical Society Monograph 147 (592), 56-180.

Loydell, D.K. 1998. Early Silurian sea-level changes. Geological Magazine 135 (4), 447-471.

Loydell, D.K. 2008. Rastrites maximus Carruthers, 1867. In: Zalasiewicz, J.A., Rushton, A.W.A., Hutt, J.E., Howe, M. (Eds), Atlas of Graptolite Type Specimens, Folio 1. The Palaeontographical Society and the British and Irish Graptolite Group, Maidenhead, Folio 1.86.

Loydell, D.K., Frýda, J., Gutiérrez-Marco, J.C. 2015. The Aeronian/Telychian (Llandovery, Silurian) boundary, with particular reference to sections around the El Pintado reservoir, Seville Province, Spain. Bulletin of Geosciences 90 (4), 743-794.

Loydell, D.K., Štorch, P., Melchin, M.J. 1993. Taxonomy, evolution and biostratigraphical importance of the Llandovery graptolite Spirograptus. Palaeontology 36, 909-926.

Melchin, M.J., Sadler, P.M., Cramer, B.D, Cooper, R.A., Gradstein, F.M., Hammer, O. 2012. The Silurian Period. In: Gradstein, F.M., Ogg, J.G., Schmitz, M.D., Ogg, G.M. (Eds), The Geologic Time Scale 2012. Elsevier, Oxford, 525-558.
Sačanski, V. 1993. Boundaries of the Silurian System in Bulgaria defined by graptolites. Geologica Balcanica 23 (1), 25-33.

Sachanski, V. 2015. The Silurian in the West Balkan Mts. (Svoge Unit, Srednogorie Zone) - 110 years later. Geologica Balcanica 44 (1-3), 3-15.

Sachanski, V., Tenchov, Y. 1993. Lithostratigraphical subdivision of the Silurian deposits in the Svoge anticline. Review of the Bulgarian Geological Society 54 (1), 71-81 (in Bulgarian, with English abstract).

Štorch, P. 1994. Graptolite biostratigraphy of the Lower Silurian (Llandovery and Wenlock) of Bohemia. Geological Journal 29, 137-165.

Storch, P. 1998. Graptolites of the Pribylograptus leptotheca and Lituigraptus convolutus biozones of Tmaň (Silurian, Czech Republic). Journal of the Czech Geological Society 43 (4), 209-272.

Štorch, P. 2000a. Parapetalolithus palmeus (Barrande, 1850). In: Zalasiewicz, J.A., Rushton, A.W.A., Hutt, J.E., Howe, M. (Eds), Atlas of Graptolite Type Specimens, Folio 1. The Paleontographical Society and the British and Irish Graptolite Group, Maidenhead, Folio 1.71.

Štorch, P. 2000b. Mograptus marri Perrner. In: Zalasiewicz, J.A., Rushton, A.W.A., Hutt, J.E., Howe, M. (Eds), Atlas of Graptolite Type Specimens, Folio 1. The Paleontographical Society and the British and Irish Graptolite Group, Maidenhead, Folio 1.59.

Štorch, P. 2008. Cephalograptus cometa extremas Bouček \& Přibyl, 1941. In: Zalasiewicz, J.A., Rushton, A.W.A. (Eds), Atlas of Graptolite Type Specimens, Folio 2. The Paleontographical Society and the British and Irish Graptolite Group, Maidenhead, Folio 2.23.

Štorch, P., Frýda, J. 2012. The late Aeronian graptolite sedgwickii Event, associated positive carbon isotope excursion and facies changes in the Prague Synform (Barrandian area, Bohemia). Geological Magazine 149 (6), 1089-1106.

Štorch, P., Loydell, D.K. 1992. Graptolites of the Rastrites linnaei Group from the European Llandovery (Lower Silurian). Neues Jahrbuch für Geologie und Paläontologie Abhandlungen 184 (1), 63-86.

Štorch, P., Mikuláš, R., Frýda, J. 2011. The Silurian sedgwickii Event: Carbon isotope excursion, graptolite mass extinction, sedimentary record. In: Přikryl, T., Bosák, P. (Eds), Research Reports 2009. Institute of Geology of the Academy of Sciences of the Czech Republic, Prague, 26-27.

Yanev, S. 2000. Palaeozoic terranes of the Balkan Peninsula in the framework of Pangea assembly. Palaeogeography, Palaeoclimatology, Palaeoecology 161 (1-2), 151-177.

Yanev, S., Lakova, I., Boncheva, I., Sachanski, V. 2005. The Moesian and Balkan Terranes in Bulgaria: Palaeozoic marine basin development, palaeogeography and tectonic evolution. Geologica Belgica 8, 185-192.

Zalasiewicz, J. 2000. Monograptus (Diversograptus?) capillaris (Carruthers, 1867). In: Zalasiewicz, J.A., Rushton, A.W.A., Hutt, J.E., Howe, M. (Eds), Atlas of Graptolite Type Specimens, Folio 1. The Paleontographical Society and the British and Irish Graptolite Group, Maidenhead, Folio 1.66.

Zalasiewicz, J. 2008. Torquigraptus denticulatus (Törnquist, 1899). In: Zalasiewicz, J.A., Rushton, A.W.A. (Eds), Atlas of Graptolite Type Specimens, Folio 2. The Paleontographical Society and the British and Irish Graptolite Group, Maidenhead, Folio 2.15.

Zalasiewicz, J.A., Taylor, L., Rushton A.W.A., Loydell, D.K., Rickards R.B., Williams, M. 2009. Graptolites in British stratigraphy. Geological Magazine 146 (6), 785-850. 